\title{
FOREIGN ECONOMIC SECURITY STRENGTHENING IN THE CONTEXT OF GEOPOLITICAL REORIENTATION
}

\author{
Fleychuk Maria ${ }^{1}$, Ganski Uladzimir ${ }^{2}$, Kutsyk Valentyna ${ }^{3}$, Tsybouski Viktar $^{\mathbf{4}}$ \\ ${ }^{1}$ Prof. Dr. habil. National Institute for Strategic Studies. 2 a Tershakovtsiv str. 79005 Lviv. Ukraine. \\ Tel.+380964522859. E-mail: fleychukm@gmail.com \\ ${ }^{2}$ Assoc. prof. Dr. Institute of Entrepreneurial Activity. 11 Serafimovič str. 220033 Minsk, Belarus. \\ Tel.+375298122244.E-mail: ganski@tut.by \\ ${ }^{3}$ Assoc. prof. Dr. Lviv University of Trade and Economics. 10 Tugan-Baranovsky str. 79005 Lviv. \\ Ukraine.Tel.+380961840604.E-mail:my_lviv@i.ua \\ ${ }^{4}$ Assoc. prof. Dr. Institute of Entrepreneurial Activity. 11 Serafimovič str. 220033 Minsk, Belarus. \\ Tel.+375172984359.E-mail: uoipd@tut.by
}

Received 1012 2018; accepted 08032019

The relevance of the article is due to the dynamic political, social and economic processes, which carry both threats and opportunities for the foreign economic security of state, provision of which becomes a key task of government and key to existence of state itself. The purpose of the article is to identify the threats to foreign economic security in the context of geopolitical reorientation and to determine, on this basis, ways to strengthen of foreign economic security. Research methods: comparative analysis and assessment of the dynamics of the main indicators of the national economy of Ukraine and its interaction with the external environment in 2006-2017. Results: identified internal and external threats to national economic security; identified key factors of foreign economic security of Ukraine; proposed ways to strengthen foreign economic security.

For achieving positive trends in macroeconomical indicators government should use modern mathematical and econometrical methods to monitoring situation as to national economic security and adjusting geopolitical strategy according to these indicators.

Key words: foreign economic security, geopolitical reorientation, international economic relations, strengthening external competitiveness, Ukraine's economy.

JEL Codes: F52, F68.

\section{Introduction}

The modern stage of globalizing economic relations creates opportunities for development and, at the same time, new threats and challenges to the security of national economies. The vulnerability of the national economic macro-system to global challenges and geopolitical conflicts is most likely to be reflected in trade relations between the country and its partners. Accordingly, there is a direct link between

Copyright (C) 2019 The Authors. Published by Vytautas Magnus University, Lithuanian Institute of Agrarian Economics. This is an open access article distributed under the terms of the Creative Commons Attribution NonCommercial 4.0 (CC BY-NC 4.0) license, which permits unrestricted use, distribution, and reproduction in any medium, provided the original author and source are credited. The material cannot be used for commercial purposes. 
international economic security and the external economic component of national security that can be traced by comparing the results of the analysis of geopolitical changes and the dynamics of the main indicators of country's foreign trade. Participation of a country in the international division of labor and the influence of external factors on the competitiveness of the national economy actualize the problem of maintaining foreign economic security as the basis for counteracting the impact of threats to national security in a globalized world. The security of the process of national economy's integration into the system of world economic relations depends on the state's ability to resolve conflicts that arise because of the need to comply with the requirements of international institutions while ensuring the protection of national economic interests, market and producers.

The foreign economic security in the global economy had become an important subject of scientific research in numerous research papers of both domestic and foreign scientists. McGuire (1995) explored the Defense economics and international security. Long (1992) studied the questions of national security versus national welfare in foreign economic policy. Walter (2015) explored the open economy politics and international security dynamics: realizing the explanation international cooperation in financial crises. Tang (2015) carried out rethinking economic security in a globalized world. Vlasyuk (2016) in his articles considered the priorities of Ukraine's competitiveness ensuring in the sphere of foreign trade relations. At the same time, there is no unequivocally acceptable list of financial sustainability indicators. Both at the level of international institutions and financial regulators of countries, work is under way to identify the most important indicators for the implementation of the Financial System Assessment Program (FSAP). In the same time, it is not going within economic security indicators improving policy. This program is a joint initiative of the IMF and the World Bank and is designed to help create systems for early diagnosis of the vulnerabilities of financial markets and to develop effective measures to deal with the development of possible problems in the financial sector. This question was considered in the works of Ellull (2015), Langfield and other (2014), Altukhova and other (2016), Baturina and Litvinenko (2018), Silvestrov (2014). As a rule, the basic set (capital adequacy of credit institutions and the quality of their assets, profit and profitability, liquidity, sensitivity to market risks) and an additional set of financial stability indicators are usually among the indicators considered. The latter may include indicators that characterize the state of depository institutions, non-bank financial institutions, corporate sector (enterprises), household sector, and real estate markets more than 20 indicators (BIS, 2013).

Parakhonskyi, Yavorska and Reznikova (2013) carried out the research of international security environment in the context of challenges and solutions for international security of Ukraine. Varnaliy, Onishchenko and Masliy (2016) explored questions of threat prevention mechanisms of Ukraine's economic security, etc. Consequently, focus is on developing measures to counter external threats or adapting foreign economic policy to globalization challenges. At the same time, insufficient attention is paid to the internal factors of foreign economic security, which determine 
the adaptive capacity of the country to the external environment changes. Thus, to solve these problems they should expand researching in the sphere of foreign economic security indicator strengthening in the context of separate states geopolitical reorientation and world order changing.

The research object is the foreign economic security of a national economy. The research subject includes economic security indicators (the share of the leading partner country in the total volume of foreign trade, the share of high-tech products in the export of goods, the share of high-tech products in the import of goods, coefficient of import coverage by export, export dependency ratio, coefficient of technological dependence, integral indicator of foreign economic security etc.).

The goal of the article is to identify the threats to foreign economic security in the context of geopolitical reorientation and to determine, on this basis, ways to strengthen of foreign economic security. Detection of these is possible based on a solid systematic structural analysis, the identification of quantitative and qualitative changes in the development of components of foreign economic security and the generalization of the identified phenomena and processes. Scientific literature review and modeling methods suggested quantitative empirical study to be performed in finding actual evidence for solutions of defined scientific problem. Descriptive statistical analysis methods were applied to organize the research results. It is obvious that the level of economic security is not a goal, but, above all, a factor and a consequence of the high level of socioeconomic development of the state and its place in the global economy. To verify the hypothesis expressed, we will present the results of the assessment of the relationship between the integral indicator of Ukraine's foreign economic security and the global competitiveness index for the period of 2006-2017. We will apply the Curve Expert 1.4 software programming tool for non-linear programming.

\section{Research results and discussion}

In our opinion, foreign economic security is an integral part of the economic security of any state, which means minimizing the losses of the state from influence of negative foreign economic factors, creation of favorable conditions for development national economy through its active participation in the world division of labor, the correspondence of foreign economic activity to national economic interests.

Currently, foreign economic activity Ukraine is largely liberalized without the state having the appropriate controlling functions and taking into account the specifics transition period, which poses a grave threat to the economic security of Ukraine.

We have carried out the classification of the components of foreign economic security of the country and identified the main indicators and indicators for its analysis (Fig. 1). Commodity and geographical imbalances of Ukraine's exports and imports, as well as their impact on the standard of living of the population and national security testify to the lack of a state export-import strategy, which negatively affects the economic security of Ukraine as a whole. 
For the recent years, competition of leading global and regional states-leaders has been intensified for the redistribution of spheres of influence, particularly in the post-Soviet countries. Ukraine's struggle for independence, as a non-aligned country, is taking place in complicated and dangerous conditions of the conflict of interests between the world most influential states. These external threats increase the negative impact of internal threats that arise within sociopolitical transformations in Ukraine, which has become an object of asymmetric political, economic, information pressure from the stronger states (Fleychuk, 2018).

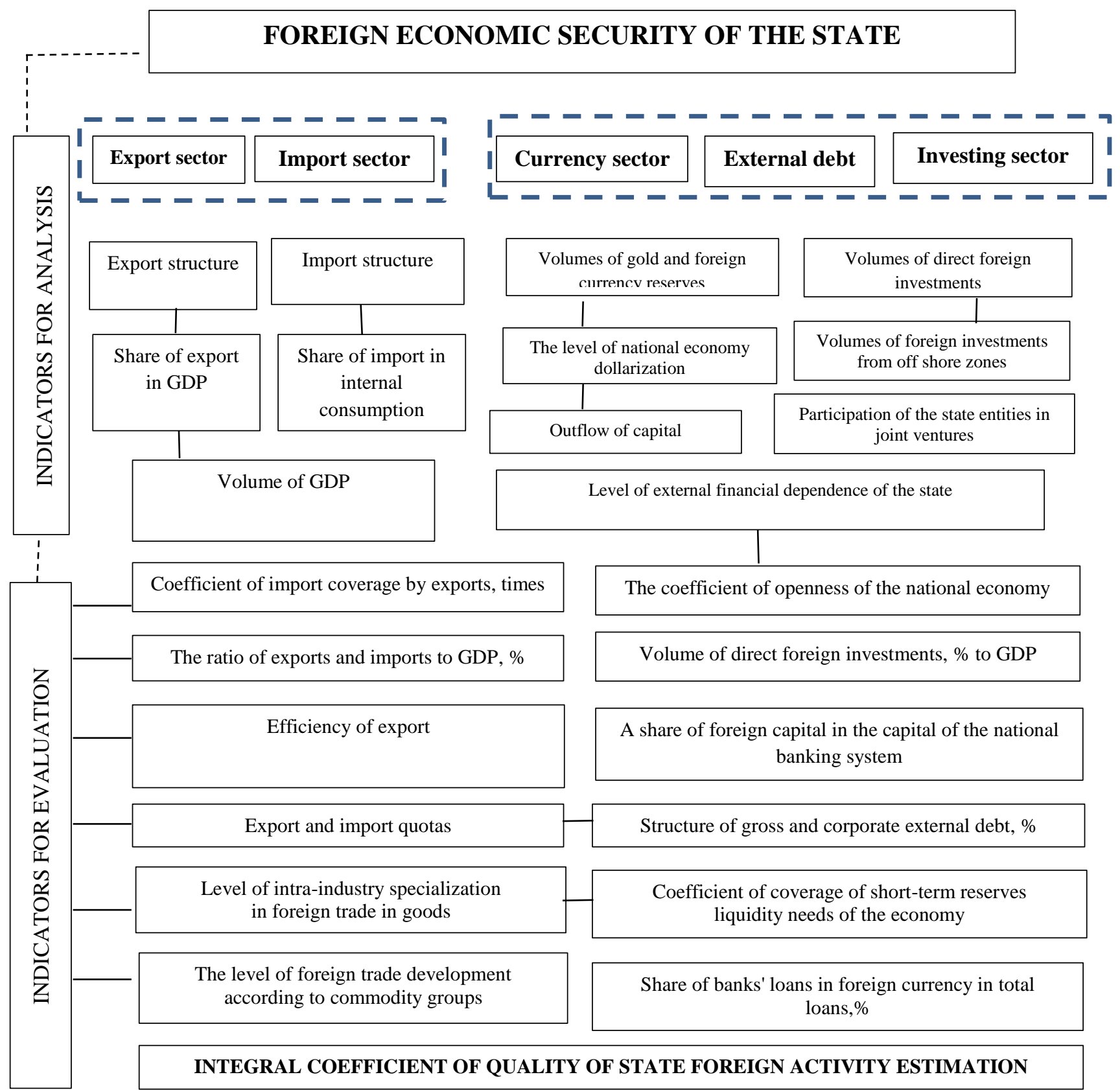

Figure 1. Indicators and the classification of the components of foreign economic security 
We consider the foreign policy of Russia as a dangerous geopolitical threat to Ukraine, and its characteristic feature, according to researchers' view, is 'an attempt to keep geopolitical control over the situation within the post-Soviet space, which contradicts the European integration course of Ukraine and a number of other states of this space" (Parakhonskyi, 2013). Under the conditions of external pressure and globalization choice of Ukraine between different external development vectors, the influence of threatening manifestations of separatism has intensified, along with political and economic crisis in the country.

Thus, the development of Ukraine's foreign economic activity is taking place in difficult geopolitical conditions. This has led to increasing negative impact of some external and internal threats. Such changes in the geopolitical situation have also opened new opportunities for the development of foreign economic relations of Ukraine, presenting domestic enterprises at new foreign markets and ensuring the conformity of domestic products to European or world standards.

Regardless of the level of management where the security assessment is carried out, the following procedure for calculating an integral indicator is used: forming a set of indicators, defining their characteristic values, normalizing indicators, determining weighting coefficients, and calculating the integral index. According to this sequence of state's economic security studies, the first stage is to form a list of indicators and to assess their status, based on a comparison of the actual values of the indicators to their thresholds. The main task of this stage is to create a database of output indicators that would ensure the correct calculation of the actual and threshold values that characterize the relevant component of economic security, considering the peculiarities of using the competitive potential of the state.

Each country, with its specific development conditions, defines a list of economic security indicators that is constantly updated. We will evaluate the foreign economic security using the following indicators: the share of the leading partner country in the foreign trade turnover; coefficients of export-import ratio to GDP; coefficient of coverage of imports by export; the share of high-tech products in the import and export of goods; coefficient of technological dependence.

In order to assess the foreign economic security of Ukraine, the indicative method of calculating the integral indicator should be applied (as one of the best in circumstances of Ukraine) - the sum of the outputs of the normalized values of statistical indicators and the corresponding weighting factors that determine the contribution of each indicator to the general level of security. According to the methodology for assessing the level of economic security, if $x_{i j}$ - some indicators, $\mathrm{j}=$ $1, \ldots, \mathrm{m} ; \mathrm{i}=1, \ldots, \mathrm{n}$, which in aggregate characterize the foreign economic activity of the country, then the integral index of foreign economic security should have the form of linear convolution:

$$
I_{i}=\sum_{J=1}^{m} a_{i j} z_{i j}
$$


where $a_{\mathrm{ij}}$ - weighting coefficients determining the degree of contribution of the $\mathrm{j}$-th indicator to the integral index of foreign economic security; $z_{i j}$ - normalized values of input indicators $\mathrm{x}_{\mathrm{ij}}$. In order to determine the weighting factors $\left(a_{i}\right)$, the model of the main components is used. The model of the main components is constructed with the use of the program "Statistics" (module "Factor Analysis"): calculation of the correlation matrix; separation of the main components and calculation of the factor loads; identification of the main components.

Normalized values of indicators are stimulants for foreign economic security and calculated as the ratio of the statistical significance of the indicator at a certain point in time (year $t$ ) to the maximum value of this indicator for the studied period. Normalizing indicators are destimulants, which growth negatively affects banking security, is carried out as a ratio of the minimum value of the indicator for the studied period and its statistical value in year $t$. The integral indicator of foreign economic security is equal to 1 when all $\mathrm{x}_{\mathrm{ij}}$ acquire the "best", or optimal, values, and 0 when all the indicators are the "worst".

The methodology of assessing the level of economic security of the state contains a list of indicators of foreign economic security (the share of import in domestic consumption, the share of import of food in domestic consumption, the share of export of the leading partner country in the total volume of foreign trade, the share of raw materials in the total export, coefficient of coverage of import by export, the ratio of volume of export (import) to GDP) and determines the thresholds of these indicators. The disadvantage of this technique is the lack of indicators on scientific and technological component of international trade.

To carry out an assessment of the level of foreign economic security of Ukraine, we supply the methodology with indicators that will allow to assess not only the quantitative characteristics of foreign economic activity, but also qualitative, which is possible due to use of such indicators as the share of high-tech products in export (import); the coefficient of technological dependence (Table 1). The positive dynamics of some indicators of foreign economic security, which normalized values are given in Table, shows the strengthening of foreign economic security in the long-term period. Thus, the value of the integral indicator of foreign economic security increased from 0.708 in 2006 to 0.817 in 2016 . The share of the leading partner country, which is still Russia, in the total volume of foreign trade, has changed most significantly. It is dangerous trends for Ukraine.

In 2016-2017 there was a gradual increase in the volume of foreign trade of Ukraine after a catastrophic decline in 2014-2015. The main reason for the decline in exports from Ukraine in 2015 was the reduction of industrial production due to military actions in Donetsk and Luhansk regions. Other, not less important, reasons for the reduction of exports were the introduction of trade restrictions on several Ukrainian goods by the Russian Federation: embargo (prohibition of imports of meat, dairy products and products of plant origin); Russia's abolition of the free trade regime with Ukraine (introduction of duties on machinery and equipment, metal products, chemical products). The occupation of the Crimea and certain parts and regional centers of 
Donetsk and Luhansk regions significantly influenced the scale of the shadow economy and the spread of corruption, which negatively affects the level of both foreign economic and national security.

However, the main preconditions for this were and remain not only the military aggression of the former "strategic partner", but such objective socioeconomic processes as: excessive concentration of capital in certain regions and by certain representatives of social and political elites, as a result of which there is a lack of effective investment and doing business and creating an excess of capital; an objective need for productive resources and goods produced by enterprises in the occupied territories and, on the other hand, enterprises and population of the occupied territories for resources and, most importantly, consumption goods; the interdependence between processes that leads to the expansion of the commodity and financial-monetary exchange, the movement of citizens within the occupied territories and regions.

Due to the crisis with Ukraine's largest trade partner, the task of diversifying export deliveries is faced by Ukrainian commodity producers, the solution of which will ensure the implementation of national interests in terms of strengthening independence and increasing the sustainability of the national economy. At the beginning of 2016, additional opportunities for access to markets of European countries were created for Ukrainian producers.

Table. 1. Normalized values (from 0 to 1 ) of indicators and integral index of foreign economic security of Ukraine, 2006-2017

\begin{tabular}{|c|c|c|c|c|c|c|c|c|}
\hline Year & 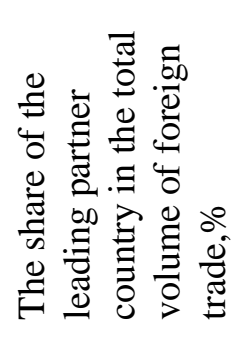 & 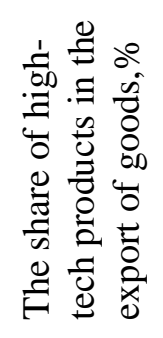 & 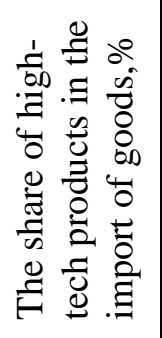 & 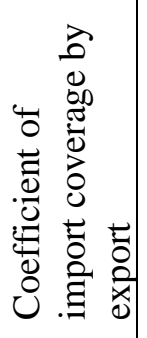 & 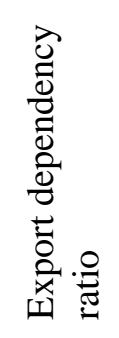 & 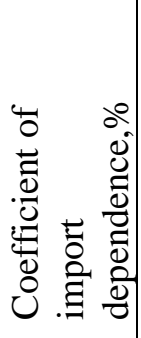 & 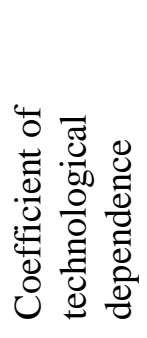 & 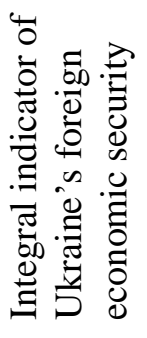 \\
\hline 2006 & 0,430 & 0,625 & 0,822 & 0,842 & 0,969 & 0,780 & 0,667 & 0,708 \\
\hline 2007 & 0,432 & 0,792 & 0,871 & 0,802 & 1,000 & 0,767 & 0,829 & 0,755 \\
\hline 2008 & 0,501 & 0,708 & 1,000 & 0,772 & 0,939 & 0,721 & 0,837 & 0,757 \\
\hline 2009 & 0,454 & 1,000 & 0,779 & 0,861 & 0,983 & 0,812 & 1,000 & 0,807 \\
\hline 2010 & 0,454 & 1,000 & 0,779 & 0,861 & 0,980 & 0,812 & 1,000 & 0,806 \\
\hline 2011 & 0,357 & 0,819 & 0,752 & 0,822 & 0,810 & 0,636 & 0,744 & 0,673 \\
\hline 2012 & 0,394 & 0,944 & 0,710 & 0,802 & 0,872 & 0,672 & 0,804 & 0,713 \\
\hline 2013 & 0,424 & 0,875 & 0,693 & 0,812 & 0,977 & 0,760 & 0,735 & 0,728 \\
\hline 2014 & 0,559 & 0,889 & 0,688 & 0,980 & 0,710 & 0,667 & 0,882 & 0,746 \\
\hline 2015 & 0,710 & 0,903 & 0,727 & 1,000 & 0,709 & 0,681 & 0,978 & 0,803 \\
\hline 2016 & 1,000 & 0,944 & 0,638 & 0,911 & 0,690 & 1,000 & 0,857 & 0,871 \\
\hline 2017 & 0,984 & 0,875 & 0,677 & 0,871 & 0,749 & 0,627 & 0,776 & 0,818 \\
\hline $\begin{array}{l}\text { Weighting } \\
\text { coefficients }\end{array}$ & 0,235 & 0,132 & 0,114 & 0,124 & 0,169 & 0,105 & 0,122 & - \\
\hline
\end{tabular}




\section{Fleychuk Maria, Ganski Uladzimir, Kutsyk Valentyna, Tsybouski Viktar. Foreign Economic Security Strenghtening in the Context of Geopolitical Reorientation}

From January 1, 2016, the in-depth and comprehensive free trade area with the EU has officially started to operate in Ukraine. Therefore, the following trade preferences are envisaged: EU customs duties for $94,7 \%$ of the commodity nomenclature of industrial goods were reduced to zero. The EU abolished customs duties for about $83,4 \%$ of agricultural and food products, tariff quotas began to operate for about $15,9 \%$; the average rate of customs duties for Ukrainian goods is reduced from $4,9 \%$ to $0,5 \%$, the weighted average - from $5,0 \%$ to $2,6 \%$; Ukrainian producers have the right to supply seven of the fifteen categories of livestock food products to the EU, and eight out of ten categories of by-products of animal origin (Sushko, 2016).

The tendency of the reduction of volumes of foreign trade of Ukraine with the EU countries, which was observed in 2013-2015 and was caused by the reduction of domestic industrial production due to the aggravation of the economic and political crisis, in 2016 was replaced by a gradual increase. According to the State Statistics Service of Ukraine, in 2016, exports of goods to the EU countries amounted 13,5 billion USD, which is $3,7 \%$ more than in 2015, and imports - 17,1 billion USD, which is $11,8 \%$ more than in 2015. In addition, in the total volume of foreign trade operations of Ukraine, the share of EU countries has increased over the past 15 years. This figure was $37,1 \%$ in exports in 2016, 43,7 \% in imports (Derzhavna..., 2018).

At the same time, there are significant disparities in the structure of exports and imports. The major share of the commodity structure of Ukrainian exports to the EU countries in 2016 consisted of products of the agro-industrial complex and food industry $-30,5 \%$ of the total exports, ferrous metals $-22,9 \%$, electric and mechanical machinery $-14,7 \%$. The share of high-tech products in exports of goods from Ukraine to the EU amounted 11,9\%, while imports from the EU countries - 21,1\%. This confirms the technological dependence of the Ukrainian economy on European producers. As expected in the projections on the consequences of Ukraine's accession to the Deep Free Trade Area with the EU (Ostashko, 2014), a significant problem is the low competitiveness of producers of machinery, equipment, vehicles on European markets, which, after a loss of the Russian market, aggravates the threats to Ukraine's foreign economic security.

Along with the aggravation of threats that arise in the process of country's integration into the world community, there is several advantages of cooperation in the sphere of trade. While being effectively used, they contribute to strengthening foreign economic, industrial, scientific and technological, investment and other state security spheres. On the other hand, the problems arising in the manufacturing sector due to the low technological level of industrial enterprises or the lack of competitiveness of products, or problems associated with low investor activity and inefficient investment structure, can lead to several threats to foreign economic activity. The manifestation of these threats is reflected in the dynamics of foreign economic security indicators.

The increase in the export dependency ratio from $34,9 \%$ in 2013 to $49,4 \%$ in 2016 indicates an increase in the threat of dependence of the country's economy on the external conditions in export markets and global price volatility, especially in commodity trade and commodity with low value added. The high import dependence 
of Ukraine (51,5\% in 2017) may lead to the loss of the domestic market. It can be caused by the displacement of domestic goods by foreign products, and the reduction of domestic production.

Assessing the degree of impact of a separate threat to the integral index of foreign economic security will identify the most dangerous ones and develop measures to eliminate them. The methodology for the study of dynamic processes in the economic system and the determination of the sensitivity of parameters at the output to the change in input parameters of the system provides for the use of a sensitivity coefficient, which is defined as the effect of the independent variable deviation $\Delta x_{i}$ on the dependent variable $y$ :

$$
U\left(t, x_{i}\right)=\lim _{\Delta x \rightarrow 0} \frac{y\left(t, x_{i, 0}+\Delta x_{i}\right)-y\left(t, x_{i, 0}\right)}{\Delta x_{i}}=\frac{d y\left(t, x_{i, 0}\right)}{d x_{i, 0}} \approx \frac{\Delta y\left(t, x_{i, 0}\right)}{\Delta x_{i, 0}} .
$$

Formula (2) allows to determine point elasticity as the limiting value of arc elasticity, provided that the growth of the factor $x$ goes to zero. To avoid inaccuracies and increase the probability of the results of calculating the sensitivity of the integral index of foreign economic security to the impact of each individual threat, it is expedient to use the coefficient of arc elasticity, which determines the percentage change of the function under the influence of the percentage change in the argument:

$$
E\left(y_{i, x_{i}}\right)=\frac{\Delta y_{i}}{\Delta x_{i}} \cdot \frac{x_{i}}{y_{i}} .
$$

According to formula (1), the integral index of foreign economic security $\left(I_{F E S}\right)$ during the investigated time interval is a function of the set of indicators $\left(x_{i}\right)$ :

$$
I_{F E S}\left(t, x_{i}\right)=f\left(x_{1}, x_{2}, \ldots, x_{i}\right) \text {. }
$$

Using the functional dependence of the integral index of foreign economic security on the set of indicators, the effect of each of the threats is determined by the coefficient of sensitivity (elasticity) in year $t$ based on the approach outlined in (Kibitkin, 2010), using the formula:

$$
C_{s}=\frac{\Delta I_{F E S}}{\Delta x_{i}} \cdot \frac{x_{i}}{I_{F E S}}
$$

where $\Delta I_{F E S}$ is the difference between the actual values of the integral index of the external security of the economy and the value of the index after the change in the statistical value of the indicator by $1 \% ; \Delta x_{i}$ - value of change of statistical value of the indicator in $\% ; x_{i}-$ actual (initial) value of the statistical indicator; $I_{F E S}$ is the actual (initial) value of the integral index of foreign economic security.

The integral index of foreign economic security is most sensitive to the change in the share of the leading partner country in the total foreign trade $\left(C_{s}=0.286\right)$, the coefficient of export dependence $\left(\mathrm{C}_{\mathrm{s}}=0.156\right)$ and the share of high-tech products in export of goods $\left(C_{s}=0.141\right)$. According to our estimates, in 2017, the greatest impact on the reduction of the integral indicator had the increase in trade with the Russia. Accordingly, we can argue that an increase in the share of the leading partner country 
in the total volume of foreign trade turnover by $1 \%$ leads to a decrease of the integral index by $0.286 \%$ under other equal conditions.

Using official statistical data, we apply the trend extrapolation based on the interpolation of the change in the share of the leading partner country in the total foreign trade turnover in 2006-2017 and will develop a forecast optimistic and pessimistic scenario for changing this indicator in the short term. With a rather high probability $\left(\mathrm{R}^{2}=0,79\right)$, we can expect a further rapid decrease in the share of the leading partner country in the total volume of Ukraine's foreign trade turnover in 2018. This forecast can be considered as an optimistic only with diversification of the external trade in Ukraine, in which the share of any other partner country will not exceed the threshold of this indicator $(30 \%)$. At the same time, as a pessimistic scenario with a relatively low probability of its realization $\left(\mathrm{R}^{2}=53,8 \%\right)$, we will take a slight increase in the share of the leading partner country in the total volumes of foreign trade turnover of Ukraine. Such changes in the geographical structure of foreign trade will not be a threat to Ukraine's economic security, as it will most likely not happen due to an increase in the share of trade with Russia and will not exceed the critical value.

At the same time, the attention should be paid to the aggravation of the threat connected with the increase of economy's openness, as evidenced by a significant increase in the import dependence over the past two years and a substantial excess of this indicator of the established limit values. The danger is also deepened by the high sensitivity of the level of foreign economic security to the change in the coefficient of export dependence: the growth of this indicator by $1 \%$ leads to a decrease of the integral index by $0,156 \%$ under other equal conditions.

Based on the constructed model of polynomial trend, the change in the indicator of Ukraine's export dependence in 2006-2017 can be defined as the most pessimistic scenario $\left(R^{2}=0,77\right)$, which implies further dependence of the domestic economy on exports for the period up to 2019 According to the optimistic scenario, with a somewhat lower probability, we can expect a relatively slower growth of Ukraine's export dependence in 2017-2019, which, the same as with a pessimistic version, does not meet the criterion of security constraints. Further growth of export dependence will increase the openness, which, due to the inefficient structure of exports, threatens to increase the dependence of domestic producers of industrial products on the conjunctural fluctuations in foreign markets. Thus, the important task of the state is to develop and implement measures to support those export-oriented enterprises that manufacture science-intensive products. In turn, the result of such measures will be changes in the structure of foreign trade of Ukraine, which will, to a certain extent, contribute to the reduction and technological dependence of the country.

From 2016, there has been a significant increase in the technological dependence of Ukraine, as evidenced by an increase in the coefficient from 1.84 in 2015 to 2,32 in 2017. The threat of the domestic economy dependence on imports of high-tech goods remains relevant, since the share of high-tech products in export of goods decreased to $6,3 \%$ in 2017 . According to the polynomial trend we can with high probability $(\mathrm{R} 2=$ 
$0,61)$ assert about the possibility of a slight increase in this indicator and the weakening of the technological dependence of the Ukrainian economy in the short-term (20182019).

According to the results of our calculations, the increase of the share of hightech products in the export of goods by $1 \%$ contributes to the growth of the integral indicator of foreign economic security by $0,141 \%$ under other equal conditions. Such high sensitivity of the level of foreign economic security to the change in the technological capacity of exports confirms the need to improve the structure of industry and to increase the production of high-tech export-oriented goods, especially importsubstituting production.

The results of this analysis lead to the conclusion that the increase of the independent variable (the integral indicator of foreign economic security) has a longterm strategic effect - during the first periods dramatically increases the level of global competitiveness of Ukraine and in the subsequent lags provides a high level of research indicator.

\section{Conclusions}

1. In general, for increasing the level of national security of countries in conditions of geopolitical reorientation, it is necessary: (a) to cultivate processes of deglobalization or alter-globalization, as opposed to globalization, and to intensify the processes and tendencies of macro-regionalization; (b) raise the level of spirituality and quality of education; (c) promote patriotism (including economic ones) instead of chauvinism and nationalism; (e) to revive traditions and strengthen the role of the uniqueness of each nation, not only from a cultural but also an economic point of view; (e) raise the level of information security of each society and counter to propaganda.

2. Along with the external threats generated by changes in the geopolitical situation and worsening of the situation on world commodity markets, level of foreign economic security is significantly influenced by internal threats connected with the inefficient structure of industrial production. Namely, the predominance of raw materials, the technological backwardness of processing industry enterprises, which causes difficulties in ensuring compliance of products with European standards and low demand for high technological products.

3. Forecast estimates of changes in the key factors of Ukraine's foreign economic security in the short-term perspective suggest that there are threatening trends due to increased export dependence and the growing technological dependence of our country due to the ineffective structure of the economy and the low competitiveness of domestic goods both on the domestic and foreign markets. In its turn, the absence or delay of state policy measures to address these problems will turn into threats those opportunities of entering the markets of the new partner countries that are opening due to a contraction of trade with Russia. 
4. In the context of the threats' aggravation of the global environment, one of the main directions of strengthening foreign economic security and ensuring participation in the international division of labor is the increase of the competitiveness of domestic producers. At the same time, internal competitiveness should be achieved based on technical and technological modernization, development of importsubstituting production, improvement of institutional mechanisms of economy regulation. Strengthening external competitiveness is possible based on bringing the quality characteristics of domestic goods in line with European technical norms and standards, as well as the introduction of the latest technologies for the production of goods with high added value.

\section{References}

Derzhavna sluzhba statystyky Ukrainy: ekonomichna statystyka. http://www.ukrstat.gov.ua/ [26 11 2018].

Fleychuk M. I., Ganski U. A. [and others] (2018) International economic relations and prospects for national development: contemporary challenges and solutions. - Daugavpils: Daugava Print. 368 p.

Kibitkin A. I. (2010) Ekonometricheskie metody ocenki chuvstvitelnosti ekonomicheskoj sistemy // Vestnik MGTU. No 1: 22-26.

Long W. J. (1992) National Security Versus National Welfare in American Foreign Economic Policy // Journal of Policy History. Vol. 4. Issue 3. P. 272-306.

McGuire M. C. (1995) Defense economics and international security. Handbook of Defense Economics. Vol. 1. - Ames: North Holland. 606 p.

Ostashko T. O., Shynkaruk L.V. (2014) Ocinka vplyvu Ugody pro asociaciju / ZVT mizh Ukrainoju ta ES na ekonomiku Ukrainy. - Kyiv: NAN Ukrainy. 102 p.

Parakhonskyi B. O., Yavorska G.M., Reznikova O. O. (2013) Mizhnarodne bezpekove seredovyshhe: vyklyky i zagrozy nacionalnij bezpeci Ukrainy. - Kyiv: Nacionalnyi instytut strategichnyh doslidzhen. 56 p.

Siew Mun Tang (2015) Rethinking economic security in a globalized world // Contemporary Politics. Vol. 21. Issue 1. 40-52.

Sushko O., Khorolskyi R., Movchan V., Miroshnichenko O. (2016) Vprovadzhujuchy Ugodu pro asociaciju Ukraina - ES: Analitychna dopovid. - Kyiv: Instytut Euro-Atlantychnoho Spivrobitnyctva. $41 \mathrm{p}$.

Varnaliy Z., Onishchenko S., Masliy A. (2016) Threat prevention mechanisms of Ukraine's economic security // Economic annals-XXI. Vol. 159. No. 5-6. 20-24.

Vlasyuk T. A. (2016) The priorities of Ukraine's competitiveness ensuring in the sphere of foreign trade relations // Scientific bulletin of Polissia. No 4. Part 1. 99105.

Walter A. (2015) Open economy politics and international security dynamics: Explaining international cooperation in financial crises // European Journal of International Relations. Vol. 22. Issue 2. 289-312. 
Ellul, A., Jotikasthira, C., Lundblad, C.T., Wang,Y. (2015). Is historical cost accounting a panacea? Market stress, incentive distortions, and gains trading // Journal of Finance. Vol 70, issue 6, 2489-2538.

Langfield, S., Liu, Z., Ota, T. (2014). Mapping the UK interbank system. Journal of Banking and Finance. Vol 45, 288-303.

Altukhova, E. V., Zotov, V. A., Markov, M. A. (2016). Methodical approaches to risk management in a regional commercial bank // The Economy of the region. Issue 1, 267-282.

Baturina, E. V., Litvinenko, A. N. (2018). Monitoring of shadow cash flows by computer modeling tools // Economics of the region. Issue 1, 326-338.

Silvestrov, S. N. (2014). The Financial Stability Board is the fourth pillar of the global financial system // Finance: Theory and practice. Issue 6, 84-91.

\title{
EKONOMINIO SAUGUMO STIPRINIMAS SANTYKIUOSE SU KITOMIS VALSTYBĖMIS GEOPOLITINIO PERSIORIENTAVIMO KONTEKSTE
}

\author{
Fleychuk Maria ${ }^{1}$, Ganski Uladzimir ${ }^{2}$, Kutsyk Valentyna ${ }^{3}$, Tsybouski Viktar $^{4}$ \\ ${ }^{1}$ Prof. dr. habil. Nacionalinis strateginiu studiju institutas, Lvovas, Ukraina \\ ${ }^{2,4}$ Doc. dr. Biznio institutas. Minskas, Baltarusija \\ ${ }^{3}$ Doc. dr. Lvovo ekonomikos ir prekybos universitetas, Lvovas, Ukraina
}

Gauta 201812 10; priimta 20190308

\section{Santrauka}

Straipsnio aktualumą diktuoja esama politinių, socialinių ir ekonominių procesų dinamika, dèl kurios valstybės ekonominiam saugumui santykiuose su kitomis valstybėmis atsiranda ne tik grèsmių, bet ir galimybių. Ekonominio saugumo užtikrinimas tampa pagrindine užduotimi vyriausybei, o, kartu, ir pagrindiniu valstybės išlikimo veiksniu. Straipsnio tikslas - nustatyti grèsmes, kylančias ekonominiam saugumui santykiuose su kitomis valstybėmis geopolitinio persiorientavimo kontekste, ir jų pagrindu nustatyti ekonominio saugumo stiprinimo būdus. Tyrimo metodai: lyginamoji analize ir Ukrainos pagrindinių nacionalinės ekonomikos rodiklių dinamikos vertinimas ir jos sąveika su išorès aplinka laikotarpiu nuo 2006 iki 2017 m. Rezultatai: nustatytos vidaus ir išorès grèsmès nacionaliniam ekonominiam saugumui; nustatyti pagrindiniai Ukrainos ekonominio saugumo santykiuose su kitomis valstybėmis veiksniai; pasiūlyti ekonominio saugumo santykiuose su kitomis valstybėmis stiprinimo būdai.

Raktiniai žodžiai: ekonominis saugumas santykiuose su kitomis valstybèmis, geopolitinis persiorientavimas, tarptautiniai ekonominiai santykiai, išorès konkurencingumo stiprinimas, Ukrainos ekonomika.

JEL kodai: F52, F68. 
Fleychuk Maria, Ganski Uladzimir, Kutsyk Valentyna, Tsybouski Viktar. Foreign Economic Security Strenghtening in the Context of Geopolitical Reorientation

* Autorius pasiteirauti 